\title{
Teaching technology needs more thought
}

\author{
British secondary schools seem to have a flair for making most things seem academic. Now there is a \\ danger of them doing that to technology.
}

BRITAIN is now almost symmetrically ambivalent about technology. On the one hand, august committees of the House of Lords utter sombre warnings that, on present trends, Britain's exports of manufactured goods will be such a steadily declining proportion of the total during the coming decade (as they have been in the past decade) that, by the end of the century, the chance of staying economically afloat will be almost negligible. The government, on the other hand, rejects this simplistic advice (which is fair) on the grounds that service industries are as worthwhile as manufacturing industries, but also urges that Britain should become more conscious of the power of technology in the modern world in case it may be possible to earn an honest penny that way. And British secondary schools, constitutionally bereft of firm guidance, do their best to please those whose voices are the most plausible, not least by trying to teach technology in secondary schools, to students from age eleven upwards. An unreflective account of some of the nonsenses that result from these good intentions can be read in a booklet published last week by the Department of Education and Science, and which is the report of an enquiry into the teaching of technology in schools carried out by a group of school inspectors, Technology and school science (HMSO, £2.00).

The starting-point for enquiry is a statement that the "technological component" of the secondary school curriculum in Britain is likely to increase because of the general recognition "that we live in an increasingly technological society" and that "living and working is such a society" requires "some contact with, and appreciation of, technology". The proposition is an unexceptionable platitude from which nobody will dissent. During the past two decades of curriculum development in British secondary schools, it has from time to time been a powerful stimulus to change. Two decades ago, for example, there were several curriculum projects designed to introduce technology as a school subject fit to be taught alongside Latin and Greek as vehicles by which students could earn grades in school-leaving examinations (which remains the chief purpose of British secondary schools). Now, another wave of enterprise is under way, fanned by the interests of organizations as different as the Department of Trade and Industry and the Fellowship of Engineering, and aided by the complicity of the organizations that provide public examinations for British schools. Before the new wave of this movement gets out of hand, it would be as well that those concerned should ask themselves what they are about.

\section{Tackling technology}

Technology is every bit as important as its well-wishers say, both as a means by which countries (even Britain) can regain a semblance of prosperity and as a component of the education of young people. The immediate issue, that with which the school inspectors' report is concerned, is how it should be handled in secondary-school classrooms. The inspectors' report is an interesting and in many ways amusing account of how young people have tackled technical exercises in British schoolrooms. Young people have drilled holes in the lids of tin cans, using them to produce jets of steam that may make mock turbinewheels spin, and have fitted clothes pegs with fins of various kinds so as to test the stability of objects moving through fluids. By most accounts, young people enjoy activities such as these, which is not surprising. There is also some anecdotal evidence that little projects give young people confidence in tackling large projects, as some are required to do as part of formal and examined courses called by names such as "applied science and technology", which is again no wonder. The question that neither the school inspectors nor their sponsors stop to ask is what all this does for the education of young people, either as professional engineers or as citizens of a new world.

\section{Foundations}

Here are some principles from which to start. First, project work in schools is, generally, a valuable activity; there should be more of it, in all kinds of contexts, but projects should stretch the imagination and not consist (as they often do) of exercises in copying out what may be found in library books. (The inspectors agree on the last qualification.) This is a strictly educational argument, in support of which there is a host of shining examples. Second, however, there is no necessary connection between projects mounted at school and an adult's later understanding of the realities of modern technology. That lesson needs to be learned, for which purpose some experience of the inspectors' brave new world in needed. One easy way of providing that in schools is to enable young people to handle the bits and pieces of modern technology, which argues for helping them to tinker with automobile engines (too often thought a demeaning activity in Britain), to use computers and sometimes to mend them. But, third, it is a disservice to young people (and their eventual employers) to pretend that there is something about technology, and project-based technolegy, that is independent of scientific understanding. The British inspectors cannot be faulted on that ground, complaining of some of what they have found in schools that this or that activity fails to provide or to evoke a proper understanding of the underlying science. (A little pedantically, they go on to complain that existing courses on applied science and technology pay too little attention to technology based on chemistry and biology.) The cruellest deception, again apparently growing in British schools, is that technology is antithetical to science, even an alternative thereto.

The inspectors are not guilty on that score, but there is every reason to suspect that too many parts of the British government are guilty of the heresy. The inspectors themselves fall into the trap of saying that "technology needs to be a compulsory part of the curriculum" if all school-leavers are to have some knowledge and experience of it. Presumably, since they consider that technology and science are inseparable, the inspectors also consider that science should be dealt with similarly. But is "knowledge" of technology sufficient, and can "experience" of it be gained except at work (not necessarily as an adult)? The British have a legend, probably untrue but relevant nevertheless, that James Watt invented the steam engine against the memory of the lid of his mother's tea-kettle lifted by the steam beneath. Many of his successors were moved to work in industry by the excitement of seeing Watt's and later machines at work. Similar experiences are possible still, but in different contexts. The present anxiety that technology should be a "compulsory part of the curriculum" unfortunately falls into the standard British trap of supposing that everything important should be taught to young people at school, and then made the basis of an examination. 